\title{
PRODUCTIVITY AND ECONOMICS OF MIXED INTERCROPPING OF POTATO WITH OTHER SHORT DURATION VEGETABLES
}

\author{
M. R. Shaheb and M. I. Nazrul \\ Senior Scientific Officer, On-Farm Research Division, \\ Bangladesh Agricultural Research Institute (BARI), Sylhet-3100, Bangladesh \\ Correspondence author: smrayhan_bari@yahoo.com
}

Key words: Mixed intercropping, equivalent yield, profitability, benefit cost ratio

\begin{abstract}
Mixed cropping has proven to be a useful approach to maximizing the crop productivity. Now a day, poverty alleviation of resource poor farmers is an important issue in Bangladesh and hence, mixed cropping system can be helpful to food security as well as to reduce poverty. The experiment was carried out at Moulvibazar and Sylhet districts during 2011-12 and 2012-13 to find out the agronomic performance of mixed intercropping of potato with different short duration vegetables crop and to increase the cropping intensity and profitability of the farmers in Sylhet region. The trial was conducted following $\mathrm{RCB}$ design with six dispersed replications. There were five treatments: $\mathrm{T}_{1}$ : sole potato $(100 \%), \mathrm{T}_{2}$ : potato $(100 \%)+$ bush bean $(50 \%), \mathrm{T}_{3}$ : potato $(100 \%)+$ garden pea $(50 \%), \mathrm{T}_{4}$ : potato $(100 \%)+$ radish $(50 \%)$ and $\mathrm{T}_{5}$ : potato $(100 \%)+$ bush bean $(25 \%)+$ garden pea $(15 \%)+$ radish $(10 \%)$ used in the trial. Results revealed that the highest equivalent yields of potato 37.09 and $35.37 \mathrm{t} \mathrm{ha}^{-1}$ were recorded in potato $(100 \%)+$ radish $(50 \%)$ mixed intercropping system from Moulvibazar and Sylhet, respectively. Cost benefit analysis also showed that highest gross returns Tk. 3,70,910 and 3,53,690 and net returns Tk. 2,65,710 and 2,48,490 and benefic benefit cost ratio 3.53 and 3.36 were recorded in the same treatment combination in both locations, respectively. So, $100 \%$ potato with 50\% radish intercropping system may be recommended as profitable mixed intercropping system in Sylhet region.
\end{abstract}

\section{Introduction}

Intercropping is an ancient and traditional agronomic practice has been recognized as a potentially befitted technology to increase crop production due to its substantial yield advantage than sole cropping. Intercropping has several advantages over monoculture, such as enhancement of efficient use of environmental factors (e.g., light, nutrient, and soil moisture) and labours, reduces the adverse effect of various biotic and abiotic stress, provides diversity of food, generates more income, offers insurance against crop failure, higher return and total productivity per unit area (Marshall and Willey, 1983; Akanda and Quayyum, 1982). Sarker et al. (2013) suggested that maize grown as intercrop with short duration vegetables like red amaranth, bush bean and garden pea may be profitable than sole maize. Several studies have also been showed that intercropping system provide higher productivity and land equivalent ratio than sole crop (Hossain and Bari, 1996; Basak et al., 2006; Razzaque et al., 2007; Alom et al. 2008 and Alom et el., 2011). Successful intercropping system gives higher cash return, total production per hectare, and diversifies production system than sole cropping (Yahock, 1979) and provides greater resources use efficiency (Pathick and Malla, 1979). Transplanted aus (T. aus) rice Transplanted aman (T. aman) rice - Fallow cropping pattern is the major cultural practice in Sylhet region. Farmers cultivate rice crop mainly in rainfed condition. The soils under these cropping pattern areas are generally heavy, clay loams to clays and the top soil quickly becomes 
dry and hard after the harvest of T. aman crop. So, a vast area in the north eastern region of Bangladesh remains fallow during the rabi season due to lack of moisture in soil.

Potato is a most important vegetable crop in Bangladesh. Generally, potato is grown as a sole crop and some farmers grow potato as mixed crop simultaneously with other crops in Sylhet region. In this system, potato is grown as a main crop and the other crops like radish, bush bean, garden pea, chilli etc. are grown as mixed intercropping of potato, chilli, mustard, radish, bush bean, garden pea etc. in line sowing method. But, proper ratio of component crops i.e. the optimum seeding ratio for a successful inter-mixed cropping system is not followed which has great effect on productivity of component crops. However, in practicing their own systems the farmers of Sylhet have been facing different problems in relation to mixed intercropping practices like planting geometry, relative sowing, seeding ratio, time of companion crops for getting maximum benefit etc. Very few studies, on mixed intercropping of potato with short duration vegetables have been reported. In view, the present trial was designed to study the feasibility and agro-economic performance of mixed intercropping of potato with different short duration vegetables crop in Sylhet.

\section{Materials and Methods}

The experiment was carried out at multilocation testing (MLT) site, Moulavibazar and farming system research and development (FSRD) site, Jalalpur, South Surma, Sylhet during the two consecutive years of 2011-12 and 2012-13. The trial was conducted in a randomized complete block $(\mathrm{RCB})$ design with six (06) dispersed replications. Five treatments viz. $\mathrm{T}_{1}$ : sole potato (100\%), $\mathrm{T}_{2}$ : potato $(100 \%)+$ bush bean $(50 \%), \mathrm{T}_{3}$ : potato $(100 \%)+$ garden pea $(50 \%), \mathrm{T}_{4}$ : potato $(100 \%)+$ radish $(50 \%)$ and $\mathrm{T}_{5}$ : potato $(100 \%)+$ bush bean $(25 \%)+$ garden pea $(15 \%)+$ radish $(10 \%)$ were used in this trial. The unit plot size was $30 \mathrm{~m}^{2}$. The five years of weather data revealed that the highest amount of average monthly rainfall occurs in June followed by August, July and May, whereas lowest amount of rainfall occurs in January followed by December and February. Rainfall increases gradually from the month of January to June and then decreases. Average maximum and minimum temperature was 31.32 and was $14.71^{\circ} \mathrm{C}$, respectively (Fig.1). The seeds of potato (var. Diamant) were sown on 07-10 December in 2011 and 22 November in 2012 at both locations with maintaining spacing of $60 \mathrm{~cm} 45 \mathrm{~cm}$. Seeds of the other crops viz., radish (var. BARI Mula 1), bush bean (local) and garden pea (BARI Motorshuti 1) were sown according to recommended seed rate 7-10 days after sowing of potato using furrow / hand drilled method in lines. Fertilizers were applied as per soil test basis and these were $\mathrm{N}_{151} \mathrm{P}_{29} \mathrm{~K}_{16} \mathrm{~S}_{14} \mathrm{Zn}_{1} \mathrm{~B}_{0}$ in the form of Urea, TSP, MoP, Gypsum, Zinc Sulphate and Boric acid, respectively. Two irrigations one each at 30 days after sowing of potato (DAS) and 45 DAS; one weeding at 30 DAS; three sprayings of Rovral fungicide @ $2 \mathrm{ml} \mathrm{L}^{-1}$ of water for controlling late blight of potato one each at 45, 55 and 65 DAS, respectively were given. All other intercultural operations were done as when necessary. Radish was harvested on 10-15 February and 15-22 January in 2012 and 2013, respectively. Bush bean and garden pea were harvested on 15-20 February and 17-27 January in 2012 and 2013, respectively. On the other hand, potato was harvested on 28 and 17 February in 2012 and 2013, respectively. Yield of individual crop was converted into potato equivalent yield on the basis of the prevailing market price of individual crop adapting the following formula (Singh et al., 1990):

$$
\text { Potato equivalent yield }=Y s p+\frac{(Y i x \times P x)}{P p}
$$


Intercropping of Potato with Short Duration Vegetables

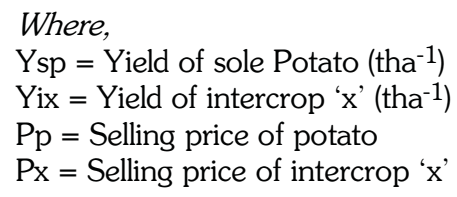

The relative yield was obtained by dividing the intercrop yield of a crop with the respective sole crop yield of that crop that was adapted from Dewit and Vander Bergh (1965) and can be accounted by the following formula:

$$
\text { The relative yield of a crop }=\frac{\text { Yleld of component crops }}{\text { Yield of sole crops }}
$$

Data on yield contributing characters were recorded from 10 randomly selected plants from each plot and yield of crops were recorded from whole plot basis at harvest. The recorded data were statistically analyzed and mean values were separated by LSD following Gomez and Gomez (1984). All types of variable costs of production were recorded and cost and benefit analysis with respect to net return was carried out to evaluate the profitability of different treatments of mixed intercropping systems.

\section{Results and Discussion}

\section{MLT site Moulvibazar}

Two years results revealed that potato tuber and intercrops yield were significantly influenced due to mixed intercropping of potato with bush bean, garden pea and radish (Table 1). In 2011-12, the highest tuber yield of potato $\left(22.70 \mathrm{t} \mathrm{ha}^{-1}\right)$ was recorded in sole potato. Results indicated that the green pod yield of bush bean $\left(4.85 \mathrm{t} \mathrm{ha}^{-1}\right)$ was recorded higher in potato $(100 \%)+$ bush bean $(50 \%)$ intercropping system than mixed intercropping of potato $(100 \%)+$ bush bean $(25 \%)+$ garden pea $(15 \%)+$ radish $(10 \%)$ treatment. Significant variations were also observed among the treatments of mixed cropping on the yields of garden pea and radish. The green pod yield of garden pea $\left(5.81 \mathrm{t} \mathrm{ha}^{-1}\right)$ was found higher in potato $(100 \%)+$ garden pea $(50 \%)$ intercropping treatment than mixed intercropping of potato $(100 \%)+$ bush bean $(25 \%)+$ garden pea $(15 \%)+$ radish (10\%). Higher yield of radish $\left(22.49 \mathrm{t} \mathrm{ha}^{-1}\right)$ was recorded in potato $(100 \%)+$ radish $(50 \%)$ intercropping than potato $(100 \%)+$ bush bean $(25 \%)+$ garden pea $(15 \%)+$ radish $(10 \%)$ mixed intercropping system. The higher yields of bush bean, garden pea and radish might be due to the higher ratio of plant population in their single associations with potato than mixed cropping altogether of these vegetables with potato.

On the other hand, in 2012-13, yield of potato, bush bean, garden pea and radish were shown significant variations among the treatments of mixed cropping (Table 1). The maximum tuber yield of potato $\left(21.73 \mathrm{t} \mathrm{ha}^{-1}\right)$ was obtained in sole potato (100\%) which was statistically identical with potato $(100 \%)+$ garden pea $(50 \%)$. The intercrop yields of bushbean and garden pea 2.50 and $1.70 \mathrm{t} \mathrm{ha}^{-1}$ were obtained in potato $(100 \%)+$ bush bean $(50 \%)$ and potato $(100 \%)+$ garden pea $(50 \%)$ intercropping treatments, respectively that were higher than that of potato $(100 \%)+$ bush bean $(25 \%)+$ garden pea $(15 \%)+$ radish $(10 \%)$ mixed cropping treatment. Likewise, higher intercrop yield of radish $\left(24.15 \mathrm{t} \mathrm{ha}^{-1}\right)$ was recorded in potato $(100 \%)+$ radish $(50 \%)$ intercropping system compared to potato $(100 \%)+$ bush bean $(25 \%)+$ garden pea $(15 \%)+$ radish $(10 \%)$ mixed intercropping. 
Shaheb et al.

Table 1. Yield of potato, intercrops, equivalent and relative yield of potato as affected by mixed intercropping with other vegetables at Moulvibazar, 2011-13.

\begin{tabular}{|c|c|c|c|c|c|c|c|c|}
\hline \multirow[t]{2}{*}{ Treatments } & \multicolumn{3}{|c|}{ Potato (t ha-1) } & \multicolumn{3}{|c|}{ Intercrops (t ha-1) } & \multicolumn{2}{|c|}{ Potato yield } \\
\hline & $\begin{array}{l}2011- \\
12\end{array}$ & $\begin{array}{l}2012- \\
13\end{array}$ & Mean & $\begin{array}{l}2011- \\
12\end{array}$ & $\begin{array}{l}2012- \\
13\end{array}$ & Mean & $\begin{array}{l}\text { Equivalent } \\
\text { (tha-1) }\end{array}$ & Relative \\
\hline Potato sole (100\%) & 22.70 & 21.73 & 22.22 & - & - & - & & \\
\hline $\begin{array}{l}\text { Potato }(100 \%)+\text { Bush } \\
\text { bean }(50 \%)\end{array}$ & 18.97 & 18.75 & 18.86 & 4.85 & 2.50 & 3.68 & 26.22 & 0.85 \\
\hline $\begin{array}{l}\text { Potato }(100 \%)+ \\
\text { Garden pea (50\%) }\end{array}$ & 17.06 & 20.23 & 18.65 & 5.81 & 1.70 & 3.76 & 26.17 & 0.84 \\
\hline $\begin{array}{l}\text { Potato }(100 \%)+ \\
\text { Radish }(50 \%)\end{array}$ & 18.10 & 18.77 & 18.44 & 22.49 & 24.15 & 23.32 & 37.09 & 0.83 \\
\hline $\begin{array}{l}\text { Potato }(100 \%)+\text { Bush } \\
\text { bean }(25 \%)+\text { Garden } \\
\text { pea }(15 \%)+ \\
\text { Radish }(10 \%) \\
\end{array}$ & 16.43 & 16.27 & 16.35 & $\begin{array}{r}- \\
2.00 \\
2.15 \\
11.89 \\
\end{array}$ & $\begin{array}{l}- \\
0.82 \\
0.91 \\
8.87\end{array}$ & $\begin{array}{l}- \\
1.41 \\
1.53 \\
1.38 \\
\end{array}$ & 30.53 & 0.74 \\
\hline $\begin{array}{l}\mathrm{LSD}_{(0.05)} \\
\mathrm{CV}(0,0)\end{array}$ & $\begin{array}{l}1.43 \\
3.39\end{array}$ & $\begin{array}{l}3.79 \\
105 ?\end{array}$ & $\begin{array}{l}2.61 \\
6.96\end{array}$ & 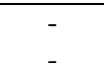 & - & - & - & - \\
\hline
\end{tabular}

"Price of output (Tk. $\mathrm{Kg}^{-1}$ ): Potato non-seed-10, Green pod of Bush bean and Garden pea-20 and Radish-8

Results revealed that the mean yield of potato was observed maximum $\left(22.22 \mathrm{t} \mathrm{ha}^{-1}\right)$ in sole potato $(100 \%)$ followed by potato $(100 \%)+$ bush bean $(50 \%)$ intercropping system $(18.86 \mathrm{t}$ $\left.\mathrm{ha}^{-1}\right)$. The mean intercrop yields of bush bean $\left(3.68 \mathrm{t} \mathrm{ha}^{-1}\right)$, garden pea $\left(3.76 \mathrm{t} \mathrm{ha}^{-1}\right)$ and radish $\left(23.32 \mathrm{t} \mathrm{ha}^{-1}\right)$ were recorded higher in potato $(100 \%)+$ bush bean $(50 \%)$, potato $(100 \%)+$ garden pea $(50 \%)$ and potato $(100 \%)+$ radish $(50 \%)$ intercropping system, respectively. The lower yields of these intercrops yield $\left(1.41,1.53\right.$ and $\left.10.38 \mathrm{t} \mathrm{ha}^{-1}\right)$ were accounted in potato $(100 \%)+$ bush bean $(25 \%)+$ garden pea $(15 \%)+$ radish $(10 \%)$ mixed cropping treatment. The lower yields in mixed cropping of four crops might be due to the lower percentage of the plant populations, higher competition among the plants for nutrients, water, light and other natural resources. Results indicated that the highest potato equivalent yield $\left(37.09 \mathrm{t} \mathrm{ha}^{-1}\right)$ was found in potato $(100 \%)+$ radish $(50 \%)$ intercropping system that was followed by potato $(100 \%)+$ bush bean $(25 \%)+$ garden pea $(15 \%)+$ radish $(10 \%)$ mixed cropping treatment where the potato equivalent yield was $30.53 \mathrm{t} \mathrm{ha}^{-1}$ (Table 1). However, the lowest potato equivalent yield was secured in sole potato (100\%) treatment and it was only $22.22 \mathrm{t} \mathrm{ha}^{-1}$. The results are in agreement with Sarker et al. (2013) who reported that all the intercrop combinations of maize intercrop with short duration vegetables like red amaranth, bush bean and garden pea were provided higher maize equivalent yield than sole maize cropping. Relative yield determines competitive ability of component crops in intercropping system. Greater value of relative yield showed more competitive ability in intercrop situation to its monoculture (Juskiw et al., 2000). However, the relative yields of potato were $0.85,0.84,0.83$ and 0.74 when potato was intercropped with bush bean, garden pea and radish, respectively (Table 1). This indicates that potato yield was reduced by $15,14,17$ and $26 \%$ of sole crop when it was intercropped with bush bean, garden pea and radish, respectively. The lower relative yield of potato in intercropping indicated that the crop faced competition for space, nutrients, light and water with other vegetables. The findings are in agreement with that of Singh (1993) and Rahman (1999).

\section{FSRD site Jalalpur, South Surma, Sylhet}

Results observed that tuber yield of potato and intercrops were significantly influenced due to mixed intercropping with bush bean, garden pea and radish or sole cropping (Table 2). In 2011- 
Intercropping of Potato with Short Duration Vegetables

12 , the maximum tuber yield of potato $\left(24.10 \mathrm{t} \mathrm{ha}^{-1}\right)$ was recorded in sole potato (100\%) that was followed by potato $(100 \%)+$ bush bean $(50 \%)$ intercropping $\left(20.83 \mathrm{t} \mathrm{ha}^{-1}\right)$ treatment. Between the treatments, the maximum green pod yield of bush bean $\left(4.89 \mathrm{tha}^{-1}\right)$ was recorded in potato $(100 \%)+$ bush bean $(50 \%)$ intercropping than mixed intercropping of potato $(100 \%)$ + bush bean $(25 \%)+$ garden pea $(15 \%)+$ radish (10\%) treatment. Significantly higher green pod yield of garden pea $\left(5.50 \mathrm{t} \mathrm{ha}^{-1}\right)$ was recorded in potato $(100 \%)+$ garden pea $(50 \%)$ intercropping treatment than mixed intercropping of potato $(100 \%)+$ bush bean $(25 \%)+$ garden pea $(15 \%)+$ radish $(10 \%)$. While, in case of radish, higher yield $\left(24.66 \mathrm{t} \mathrm{ha}^{-1}\right)$ was remarked in potato-radish intercropping than potato $(100 \%)+$ bush bean $(25 \%)+$ garden pea $(15 \%)+$ radish (10\%) mixed intercropping treatment (Table 2).

Table 2. Yield of potato, intercrops, equivalent and relative yield of potato as affected by mixed intercropping with other vegetables at Sylhet, 2011-13.

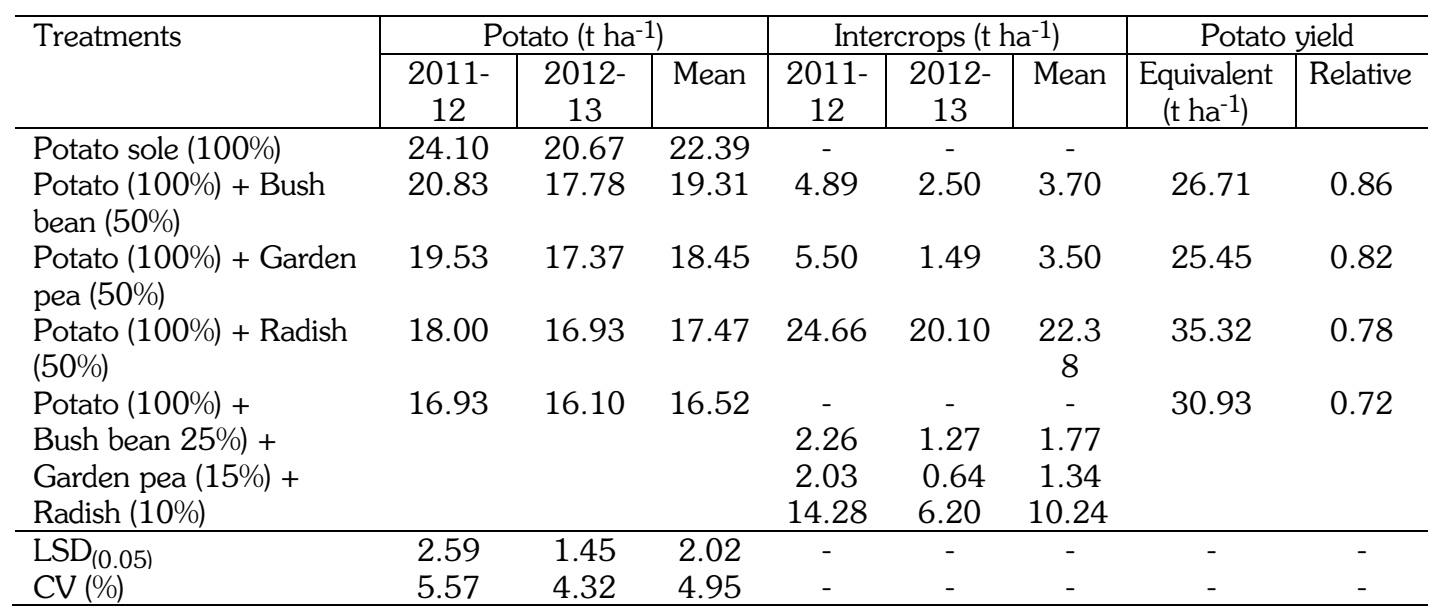

*Price of output (Tk. $\mathrm{Kg}^{-1}$ ): Potato non-seed-10, Green pod of Bush bean and Garden pea-20 and Radish-8

On the contrary, in 2012-13, the highest tuber yield of potato (20.67 t ha ${ }^{-1}$ ) was obtained by potato sole $(100 \%)$ that was also followed by potato $(100 \%)+$ bush bean $(50 \%)$ intercropping (17.78 $\mathrm{t} \mathrm{ha}^{-1}$ ) treatment. The lowest tuber yield of potato $\left(16.10 \mathrm{t} \mathrm{ha}^{-1}\right)$ was found in mixed intercropping of potato $(100 \%)+$ bush bean $(25 \%)+$ garden pea $(15 \%)+$ radish $(10 \%)$ treatment. During 2011-12 in this location, the results observed that the intercrop yields and yield attributes of bush bean, garden pea and radish differed significantly among the treatments (Table 2). However, the maximum green pod yield $\left(2.50 \mathrm{t} \mathrm{ha}^{-1}\right)$ of bush bean was recorded in potato $(100 \%)+$ bush bean $(50 \%)$ intercropping than potato $(100 \%)+$ bush bean $(25 \%)+$ garden pea $(15 \%)+$ radish $(10 \%)$ mixed intercropping treatment. Significantly, the green pod yield $\left(1.49 \mathrm{t} \mathrm{ha}^{-1}\right)$ of garden pea was obtained higher in potato $(100 \%)+$ garden pea $(50 \%)$ intercropping system than that of potato $(100 \%)+$ bush bean $(25 \%)+$ garden pea $(15 \%)+$ radish (10\%) mixed intercropping treatment. But, in case of radish, the higher yield $\left(20.10 \mathrm{t} \mathrm{ha}^{-1}\right)$ was noticed in potato $(100 \%)$ intercropped with radish $(50 \%)$ than potato $(100 \%)+$ bush bean $(25 \%)+$ garden pea $(15 \%)+$ radish $(10 \%)$ mixed intercropping treatment. Furthermore, results indicated that the mean yield of potato of $2011-12$ and 2012-13 was the maximum $(22.39 \mathrm{t}$ $\left.\mathrm{ha}^{-1}\right)$ in sole potato $(100 \%)$ followed by potato $(100 \%)+$ bush bean $(50 \%)$ intercropping system (19.31 $\left.\mathrm{t} \mathrm{ha}^{-1}\right)$ (Table 2). The mean intercrop yield of bush bean (3.70 tha-1), garden pea (3.50 $\mathrm{t}$ $\left.\mathrm{ha}^{-1}\right)$ and radish $\left(22.38 \mathrm{t} \mathrm{ha}^{-1}\right)$ were recorded higher in potato $(100 \%)+$ bush bean $(50 \%)$, potato $(100 \%)+$ garden pea $(50 \%)$ and potato (100\%) + radish (50\%) intercropping system, 
Shaheb et al.

respectively. The lower yields of these intercrops in mixed cropping systems $(1.77,1.34$ and $10.24 \mathrm{t} \mathrm{ha}^{-1}$ ) were recorded in potato $(100 \%)+$ bush bean $(25 \%)+$ garden pea $(15 \%)+$ radish (10\%) mixed intercropping treatment. This might be due to the lower percentage of the plant populations that results in lower number of tubers and pods per plant and lower number of radish per unit area, higher competition among the plants for nutrients, water, light and other natural resources. Research results revealed that the highest equivalent yield of potato $\left(35.37 t^{t} a^{-1}\right)$ was remarked in potato $(100 \%)+$ radish $(50 \%)$ intercropping system that was statistically followed by potato $(100 \%)+$ bush bean $(25 \%)+$ garden pea $(15 \%)+$ radish $(10 \%)$ mixed intercropping treatment where the potato equivalent yield was $30.93 \mathrm{t} \mathrm{ha}^{-1}$ (Table-2). However, the lowest potato equivalent yield was gained in potato $(100 \%)$ sole $\left(\mathrm{T}_{1}\right)$ treatment $\left(22.39 \mathrm{t} \mathrm{ha}^{-1}\right)$. The findings of the study are in agreement with Muhammed (2004) and Salam et al. (2012).

Study of relative yield in Sylhet revealed that the relative yields of potato were 0.86, 0.82, 0.78, 0.74 when potato was intercropped with bush bean, garden pea and radish, respectively (Table 2). This provides that potato was reduced by $14,18,22$ and $26 \%$ of sole crop when it was intercropped with bush bean, garden pea and radish, respectively. The lower relative yield of potato in intercropping system indicated that the crop faced competition for space, nutrients, light and water with vegetables. The findings are in also agreement with that of Singh (1993), Rahman (1999) and Sarker et al. (2013). In addition, very little difference was observed between the locations. However, it was found that the potato equivalent yield was higher in Sylhet (30.93 $\mathrm{t} \mathrm{ha}^{-1}$ ) than that of Moulvibazar (30.53 $\mathrm{t} \mathrm{ha}^{-1}$ ) (Table 1 and 2).

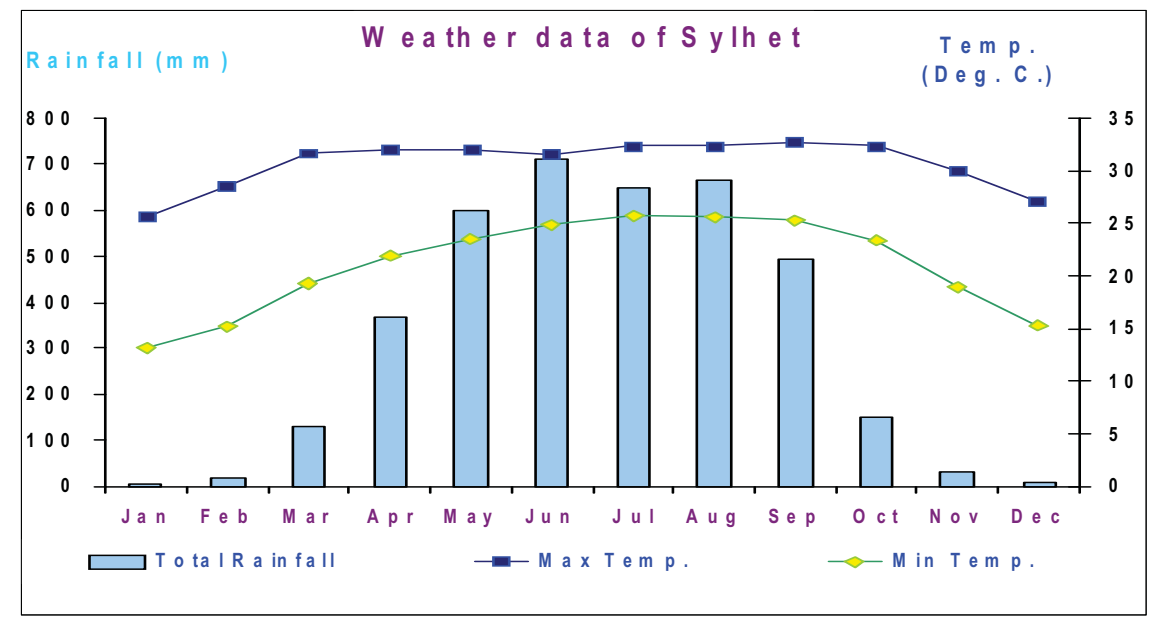

Fig. 1. Monthly average total rainfall $(\mathrm{mm})$, maximum and minimum temperatures during period of 2007-2013 in Sylhet

\section{Cost and benefit analysis}

Cost benefit analysis of the potato mean equivalent yield of 2011-12 and 2012-13 in Moulvibazar revealed that the gross return (GR) (Tk. 3,70,910) and net return (NR) (Tk. $2,65,710)$ and benefit cost ratio (BCR) $(3.53)$ were recorded in potato $(100 \%)$ intercropped with radish $(50 \%)$ intercropping system (Table 3 ) and this was followed by the treatment of potato (100\%) mixed intercropped with bush bean (25\%) + garden pea (15\%) + radish (10\%) (GR, NR and BCR were Tk. 3,05,300 and Tk. 1,94,975 and 2.77, respectively). Similar trends were also noticed in Sylhet location where the highest gross return (Tk.353690), net return (Tk. 3,48,490) 
Intercropping of Potato with Short Duration Vegetables

and BCR (3.36) were found in potato (100\%) intercropped with radish (50\%) followed by potato (100\%) mixed intercropped with bush bean (25\%), garden pea (15\%) and radish (10\%) treatment (Table 3). Interestingly, the lowest gross and net return \& BCR were found in sole potato at both Moulvibazar and Jalalpur locations. Thus, seeding combination of $100 \%$ potato intercropped with $50 \%$ radish is profitable mixed intercropping system that is provided the highest equivalent yield, monetary advantage and BCR.

Table 3. Cost and benefit analysis of mixed intercropping of potato with other vegetables at Moulvibazar and Sylhet, 2011-13

\begin{tabular}{|c|c|c|c|c|c|c|c|c|}
\hline \multirow[t]{2}{*}{ Treatments } & \multicolumn{4}{|c|}{ Moulvibazar } & \multicolumn{4}{|c|}{ Sylhet } \\
\hline & $\begin{array}{c}\text { GR } \\
\left(\text { Tk. ha }^{-1}\right)\end{array}$ & $\begin{array}{c}\text { TC } \\
(\text { Tk. ha-1) }\end{array}$ & $\begin{array}{c}\text { NR } \\
\left(\text { Tk. ha-1) }^{-1}\right.\end{array}$ & $\mathrm{BCR}$ & $\begin{array}{c}\text { GR } \\
\left(T_{k} \cdot \text { ha }^{-1}\right)\end{array}$ & $\begin{array}{c}\text { TC } \\
\left(\text { Tk. ha }^{-1}\right)\end{array}$ & $\begin{array}{c}\text { NR } \\
\left(\text { Tk. ha-1) }^{-1}\right.\end{array}$ & $\mathrm{BCR}$ \\
\hline Potato sole (100\%) & 222150 & 105400 & 116750 & 2.11 & 223850 & 105400 & 118450 & 2.12 \\
\hline $\begin{array}{l}\text { Potato }(100 \%)+\text { Bush } \\
\text { bean }(50 \%)\end{array}$ & 262200 & 108900 & 153300 & 2.41 & 267050 & 108900 & 158150 & 2.45 \\
\hline $\begin{array}{l}\text { Potato }(100 \%)+ \\
\text { Garden pea }(50 \%)\end{array}$ & 261650 & 107500 & 154150 & 2.43 & 254500 & 107500 & 147000 & 2.37 \\
\hline $\begin{array}{l}\text { Potato }(100 \%)+ \\
\text { Radish (50\%) }\end{array}$ & 370910 & 105200 & 265710 & 3.53 & 353690 & 105200 & 248490 & 3.36 \\
\hline $\begin{array}{l}\text { Potato }(100 \%)+\text { Bush } \\
\text { bean }(25 \%)+\text { Garden } \\
\text { pea }(15 \%)+\text { Radish } \\
(10 \%)\end{array}$ & 305300 & 110325 & 194975 & 2.77 & 309300 & 110325 & 198975 & 2.80 \\
\hline
\end{tabular}

*GR-Gross return, TC-Total cost, NR-Net return, BCR-Benefit cost ratio Price of input (Tk. $\left.\mathrm{kg}^{-1}\right)$

Potato seed-26

Bush bean and Garden pea seed-60 Price of output (Tk. $\left.\mathrm{kg}^{-1}\right)$

Radish seed-3000

Potato non-seed-10

Urea-12

Green pod of Bush bean -20

TSP-22

Green pod of Garden pea-20

MOP-15

Gypsum-10

Zinc Sulphate-130

\section{Conclusion}

From the above result it may be concluded that seeding combination of $100 \%$ potato with $50 \%$ radish might be profitable mixed intercropping system that offers the higher potato equivalent yield, monetary advantage of the farmers and that also leads to diversified vegetables production as well as increased cropping intensity.

\section{References}

Akanda, M. E. and M. A. Quayyum. 1982. Effect of intercropping mungbean, blackgram, soybean, cowpea, and groundnut with maize. Bangladesh J. Agril. Res. 7(1): 66-69.

Alom, M. S., M. N. Islam, B. L. Nag., M. M. Howlader and M. A. Hossain. 2011. Intercropping lentil with mukhikachu (Collocasia esculenta) at different planting systems. Bangladesh J. Agril. Res. 36(4): 669-676. 
Shaheb et al.

Alom, M. S., N. K. Paul, and M. A. Quayyum. 2008. Performance of hybrid maize (Zea mays L.) under intercropping systems with mungbean (Vigna radiata L.) in different planting methods. SAARC J. Agri. 6(2): 73-82.

Basak, N. C., S. M. A. Hossain, I. Islam and N. I. Bhuyan. 2006. Intercropping wheat with groundnut at variable plant population Bangladesh J. Agril. Res. 31(2): 207-215.

Dewit, C. T. and J. P. Vander Bergh. 1965. Competition between herbage plants. Neth. J. Agric. Sci. 13: 212-221.

Gomez K. A. and A. A. Gomez. 1984. Statistical procedures for Agricultural Research. $2^{\text {nd }}$ edn. John Wiley and Sons. New York. p.194.

Hossain. M. A. and A. K. M. A. Bari. 1996. Effect of intercropping groundnut with garlic at varying plant population levels. Bangladesh Hort. 24(1\&2): 29-34.

Juskiw, P. E., J. H. Helim and D. F. Salman. 2000. Competitive ability in mixtures of small grain cereals. Crop Sci. 40: 159-164.

Marshall, B. R. and W. Willey. 1983. Radiation interception and growth in an intercrop of pearl millet/groundnut. Field Crops Res. 7: 141-160.

Muhammed, S. T. 2004. Economics of Irrigated Oasis Farming in Manga Grassland, Yobe state, Nigeria. A M.Sc. Dissertation (unpublished). Department of Agricultural Economics and Extension. Faculty of Agriculture. University of Maiduguri. Borno state.

Pathick, D. C. and M. L. Malla. 1979. Study on the performance of crop legume under monoculture and intercrop combination, Sixth Annual Maize Development Workshop, Nepal.

Rahman, M. A. 1999. Comparative performance of intercropping in pulse and oil seeds with rainfed wheat (Triticum aestivum) in Bangladesh. Indian J. Agron. 44 (3): 504-508.

Razzaque, M. A., S. Rafiquzzaman, M. M. Bazzaz, M. A. Ali and M. M. R. Talukdar. 2007. Study on the intercropping groundnut with chilli at different plant populations. Bangladesh J. Agril. Res. 32(1): 37-43.

Salam, A. R. Y., P. V. Kwaghe and A. I. Azare. 2012. A Study on relative profitability of sole and mixed cropping enterprises among smallholder irrigation farmers in the Hadejia-Nguru Wetlands of Northeastern Nigeria. Global Res. J. Agril. Biol. Sci. 3(4): 324-329.

Sarker, U. K., S. Dey, S. Kundu and M. A. Awal. 2013. On-farm study on intercropping of hybrid maize with short duration vegetables. J. Bangladesh Agril. Univ. 11(1): 1-4.

Singh, C. V., R. K. Singh and V. S. Chauhan. 1990. Relative performance of pigeonpea genotype in sole and rice intercrop systems. Intl. Pigeonpea Newsl. 17: 19-20.

Singh, R. V. 1993. Production potential and economics of vegetables with rainfed Okra. Indian J. Hort. 50(10): 73-76.

Yahock, J. Y. 1979. Crops and cropping pattern of the Savanna region of Nigeria. The Kaduna situation. Paper presented at the international intercropping workshop, January, 10-13, 1779. ICRIST, Hyderabad, India. 